\title{
TRAVELLING TO MUNICIPAL MARKETS: AN APPROACH TO CHEESE ON OFFER
}

\author{
Francesc FUSTÉ-FORNÉ ${ }^{a}$
}

${ }^{a}$ Faculty of Tourism, University of Girona. Plaça Josep Ferrater i Móra 1, 17004, Girona, Catalonia, Spain. Email: researchexperiencetourism@gmail.com; francesc.fusteforne@udg.edu.

Cite this article: Fusté-Forné, F. (2019). Travelling to municipal markets: an approach to cheese on offer. Deturope, 11(2), 22-29.

\begin{abstract}
Markets are increasingly considered as gastronomy tourism attractions, food - and its origin - becoming a meaningful souvenir for visitors and tourists. Within this context, this research note aims to analyse the origin of cheeses delivered in city markets. To achieve it, the Spanish municipal market of Valencia was studied, where a total of 267 cheeses were classified according to their provenance. Findings show a similar presence of local, national and international cheeses. The originality of this study lies on the implications that the origin of food may have for cultural, gastronomy and cheese tourism practices.
\end{abstract}

Keywords: food tourism, gastronomy, local markets, Spain, supply chain.

\section{INTRODUCTION, CONTEXT AND AIM OF THE STUDY}

Cultural, economic and tourist importance of food tourism practices meant an increase of food and tourism based research in recent years (see, for example, Chen \& Huang, 2016; Ellis, Park, Kim, \& Yeoman, 2018). Food tourism is understood as a type of tourism where visitors get immersed into the identity of a local culture through its gastronomy (see Bèssiere \& Tière, 2013; Sidali, Kastenholz, \& Bianchi, 2015; Sims, 2009). This is particularly applied to special interest tourisms, or niche tourisms, such as cheese tourism. Linkages between cheese and tourism have been studied in countries like Brazil (França, 2012), Costa Rica (Blanco \& Gómez, 2010; Boukris 2013), Canada (Dumas, Menvielle, Perreault, \& Pettigrew, 2006), Italy (Cantarelli, 2001), France (Delfosse, 2017), Mexico (Thomé, Vizcarra \& Espinoza, 2015), New Zealand (Fusté-Forné, 2016a), or Spain (Fusté-Forné, 2015; Fusté-Forné, 2016b). In particular, cheese tourists aim to discover food cultures through cheese. Cheese tourism involves visits to areas of cheese making and milk production. Also, visits to food markets are among the different possibilities offered by food tourism practices (Everett, 2016; Hall, Sharples, Mitchell, Macionis, \& Cambourne, 2003; Hall \& Sharples, 2008). 
Here, Spain is a country that acknowledges a large and long tradition in milk production and cheese making. Local producers of cheese - with more than twenty Protected Designations of Origin -, and events surrounding this product are abundant and present all over the country. In this sense, food markets are a vital antecedent of a selling point where local produce - namely cheese - and tourism perform together. While markets have evolved from local venues to tourist landmarks, they still represent an avenue to experience local senses of place (Britton, 1991). Also, recent studies deal with markets as relevant spaces for tourism experiences (CrespíVallbona \& Domínguez, 2015; Dimitrovski \& Crespí-Vallbona, 2017; García Henche, 2017; Hall, 2016; Medina, 2008). This research note approaches local produce in markets as one of these host-guest encounters. In particular, the objective of this study is to analyse the origin of cheeses delivered in Spanish municipal markets.

Products' provenance is a key marker of cultural identities, whose place meaning is showcased in markets. Within the linkages between food and tourism, this research argues that food - and particularly cheese - travels through tourism as people and cultures do. Also, the attachments to gastronomy - as it is a foundational cultural aspect - can be experienced in markets. The diversity of products currently available at retail points shows strong evidence on the influence that global food processes have on food identities, and how culinary cosmopolitanism may shape both resident and tourist ways of life - departing from the origin of the products they consume. In line with this, recent research has particularly reviewed the importance of food supply chains in tourism industry (Roy, Hall \& Ballantine, 2016; 2017; Smith \& Xiao, 2008).

\section{STUDY METHOD}

This research aims to study the offer of cheese in municipal markets. In order to achieve this purpose, one of the most important markets in Spain was examined. Located in Valencia, eastern Spain on the Mediterranean coast, the municipal market of Valencia is the most important Spanish market with regards to fresh produce, and one of the biggest in Europe. In particular, the market counts on up to 27 food stands that sell cheese. To carry out the research, 14 of them were randomly selected in situ by the researcher. Data collection field work was conducted during the month of May, 2018. A total of 267 cheese types were classified according to their provenance. As displayed in Tab. 1 below, local (Valencia's region), national (Spain), and international cheeses were identified. 


\section{RESULTS}

Results of this study primarily show the dominance of local and national produce - representing an aggregate of two-thirds of the study sample.

Table 1 Provenance of cheese delivered in the municipal market of Valencia, Spain

\begin{tabular}{c|cccc|} 
Origin & Local & National & International & Total \\
\hline $\mathrm{N}$ & 76 & 101 & 90 & 267 \\
\hline$\%$ & $28,5 \%$ & $37,8 \%$ & $33,7 \%$ & $100,0 \%$
\end{tabular}

Source: Own source

Fig. 1 and Fig. 2 provide a detailed distribution of cheeses' origin. Fig. 1 shows the provenance of cheeses in the context of Spanish regions. Later, in Fig. 2 are highlighted the European countries from where the cheeses available in Valencia's market are originated.

Figure 1 Spanish geographical origins of cheese delivered in the municipal market of Valencia, Spain

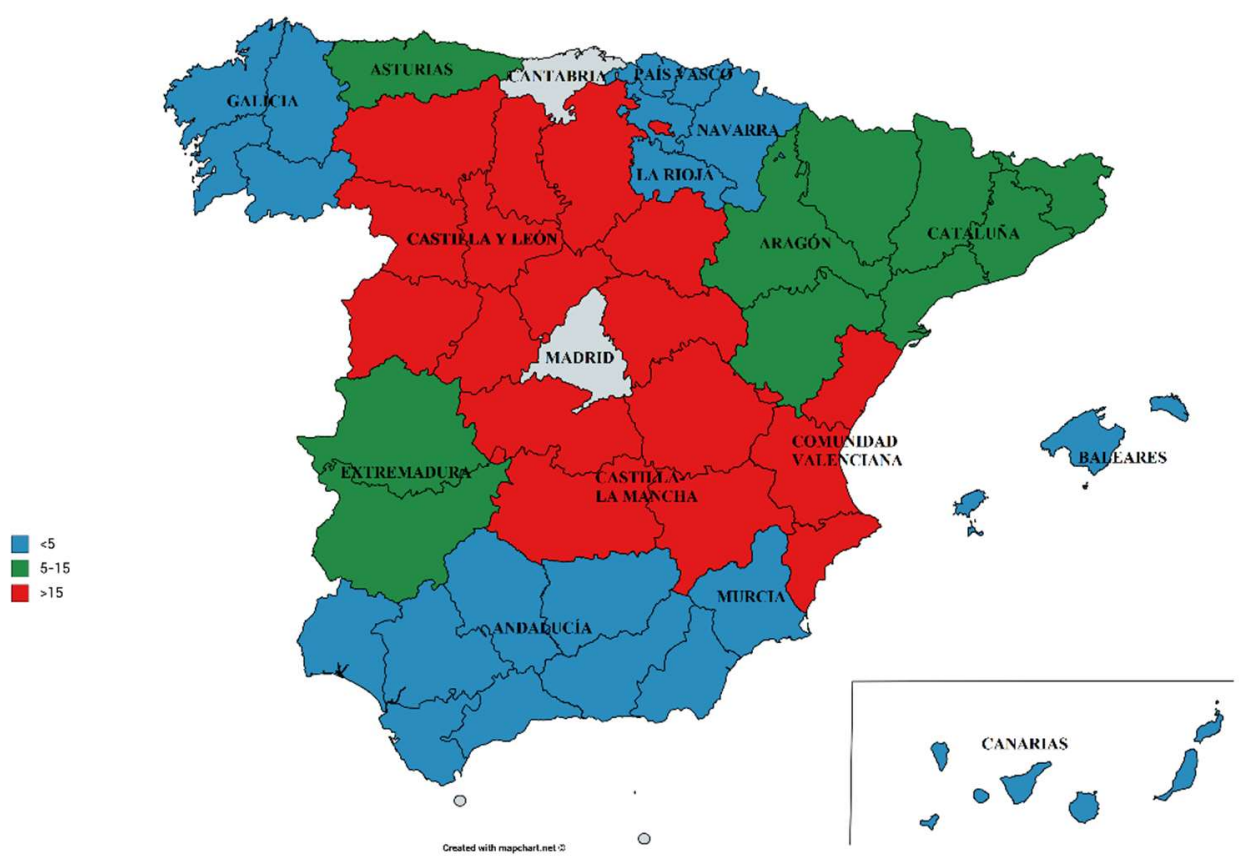

Source: Own source from http://mapchart.net 
Figure 2 European geographical origins of cheese delivered in the municipal market of Valencia, Spain

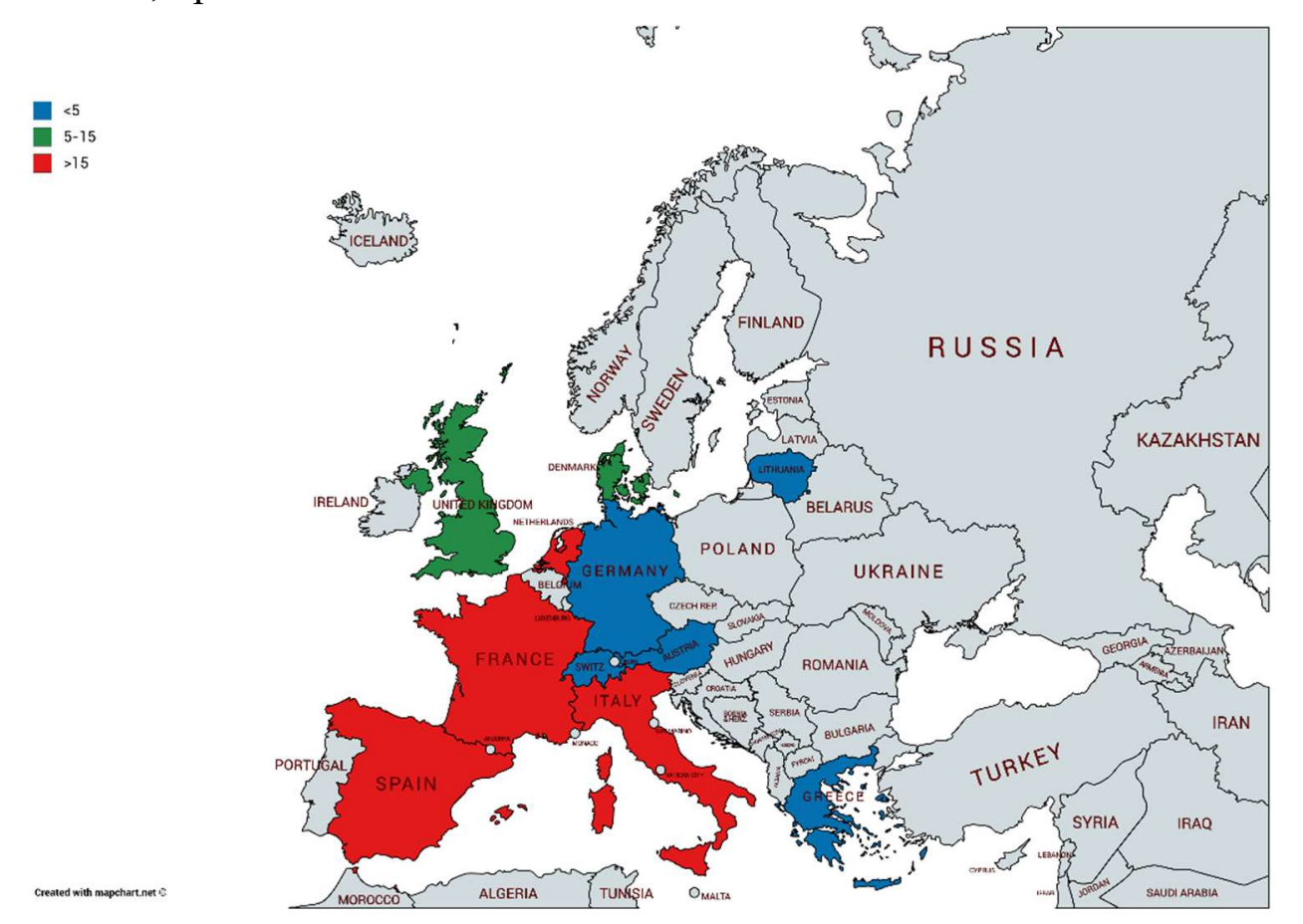

Source: Own source from http://mapchart.net

Data shows that almost a third of the products have a local origin. Those cheeses that convey the Valencia sense of place are, for example, artisanal cheeses like pistachios or servilleta cheeses (Fig. 3). Also, national products have a significant weight (almost 4 out of 10 cheeses come from the Spanish territory). Here, there are many Spanish cheeses with Protected Designations of Origin - Manchego or Zamorano cheeses are predominant within the Spanish cheesescapes, together with Galician cheeses such as Queso Tetilla (Figure 4). In addition, cheeses from international markets represent a remarkable weight - one-third of the sample, higher than local produce. However, all international cheeses studied were originated in European countries. In particular, these include cheeses like Italian Gorgonzola, Swiss Gruyère, Danish Havarti, Dutch Gouda, French Alps cheeses or English blue cheeses (see for example Fig. 4).

From the results of this research it is possible to further analyse to what extent local markets as an amalgam of foods are a means of proximity and place identity communication. Also, this note may lead to the study of city markets' potential as spaces of authenticity - and what type of authenticity -, cultural diversity, and gastronomy heterogeneity in the context of food (tourism) practices in urban contexts.

Markets, as spaces of social and cultural exchange, have nowadays strengthened as tourist landmarks. And cheese may perform inside as a specific tourist attraction. Cheese as a product opens a wide range of local-global attractiveness for food tourists and food tourism. With a 
significant place attachment role, cheeses easily move from local to global spheres. But what type of cheese is reaching into home kitchens, and what type of cheese is delivered both to residents and tourists in markets? This research draws a picture of it through a specific case of a Spanish market.

Figure 3 Local cheeses delivered in the municipal market of Valencia, Spain

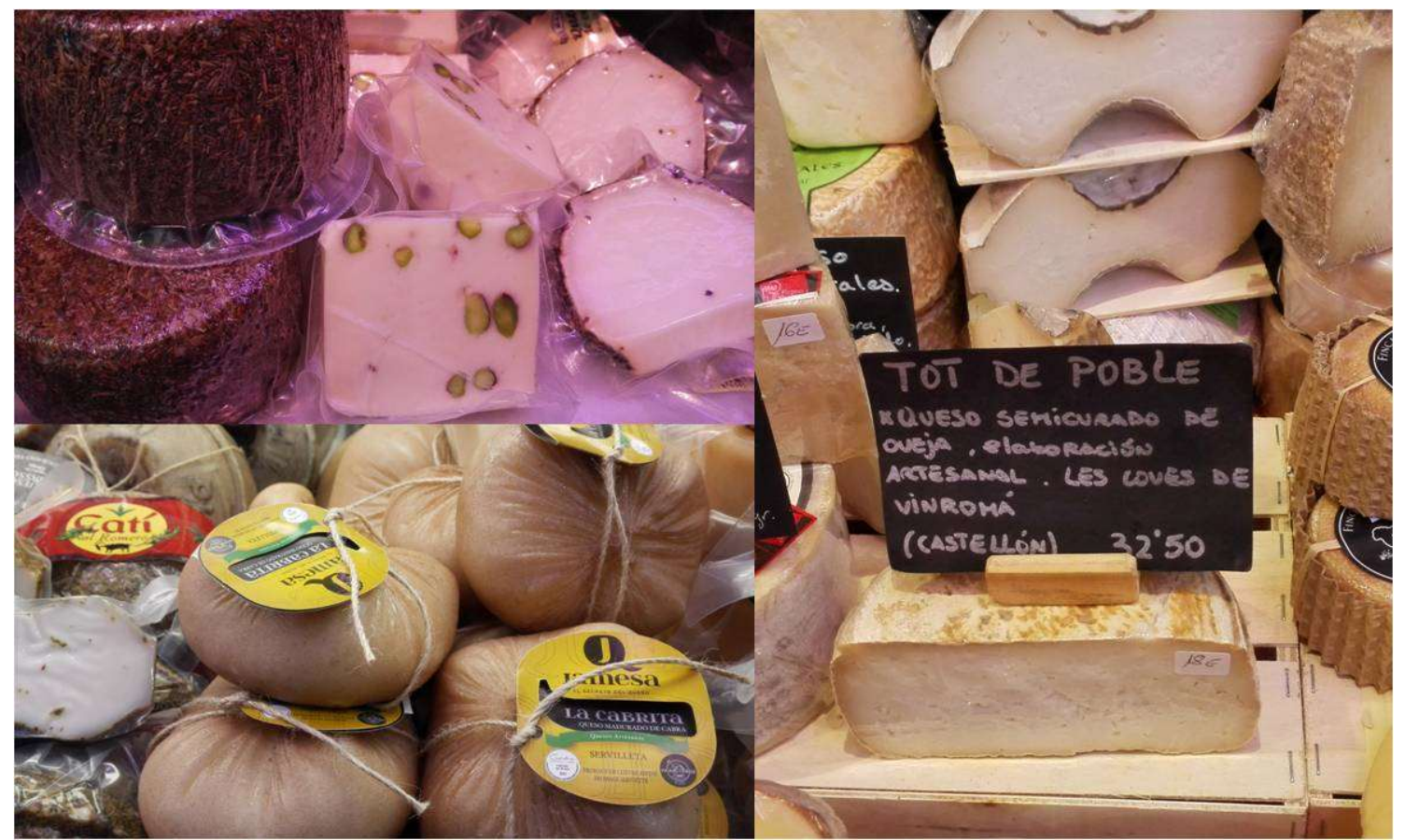

Source: Own source

Figure 4 Non-local cheeses delivered in the municipal market of Valencia, Spain

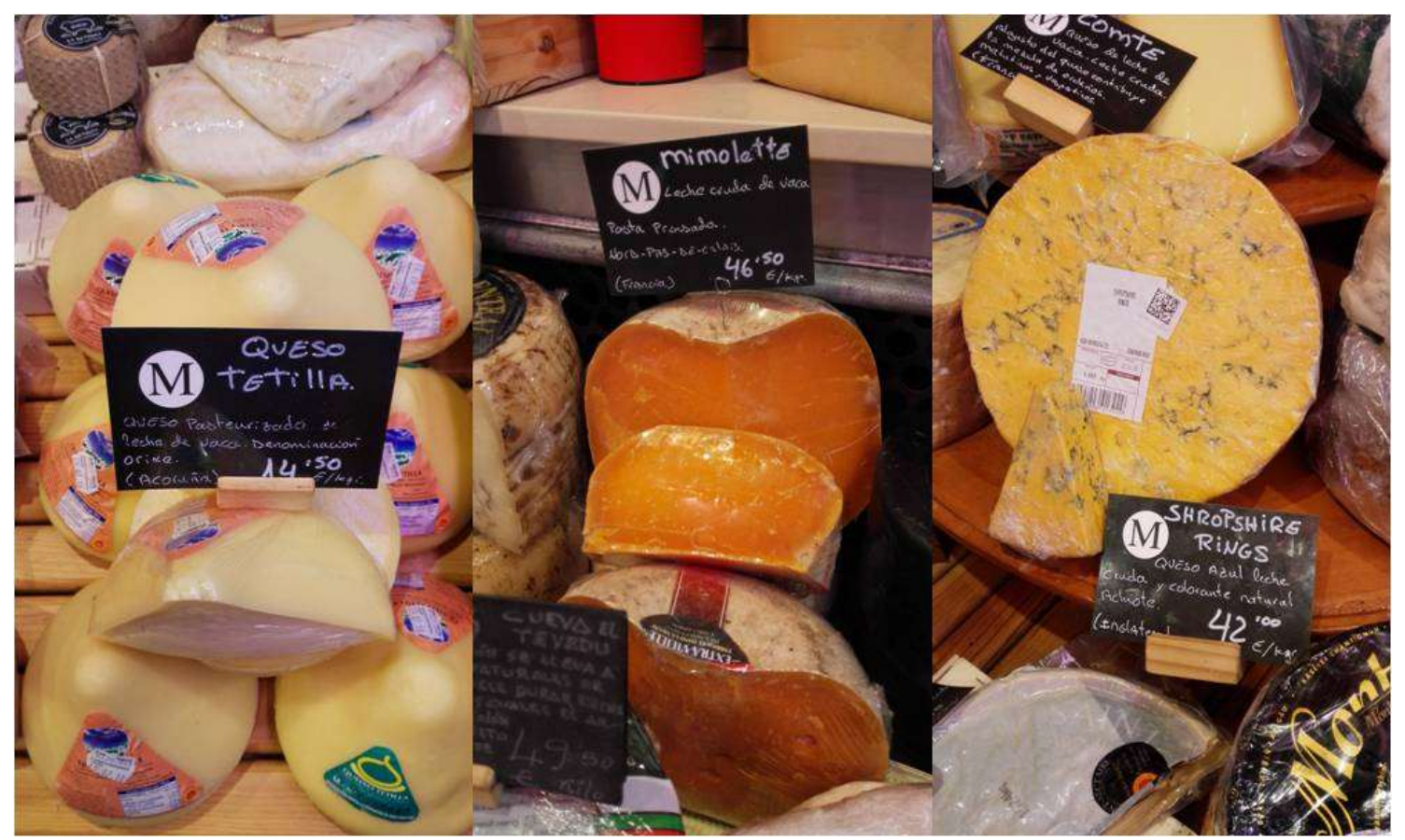

Source: Own source 


\section{CONCLUDING REMARK}

This research note contributes to the understanding of food in cities, and the role that food plays in daily habits of both locals and tourists, which is particularly relevant for food tourism planners and managers. Thus, this research provides a new approach to the understanding of foods' mobility and products' delivery from a supply perspective. Further research could focus on the reasons why buyers - both local customers and visitors - prefer one cheese to another and what are the implications for issues like food and wine pairing (see, for example, Harrington $\&$ Seo, 2015).

Moreover, upcoming multidisciplinary research should also deep on whether or not markets play a significant regional economic impact. From the assumption that artisans and sellers are able to turn cheese - or other products - into a powerful tourist resource that conveys a specific identity, it is also important to further scrutinize the meanings attached to the from farm to fork processes - as supported in this paper, local globalized food supplied to a global localized demand.

\section{REFERENCES}

Bessière, J., \& Tibère, L. (2013). Traditional food and tourism: French tourist experience and food heritage in rural spaces. Journal of Science of Food and Agriculture, 93(14), 34203425 .

Blanco, M., \& Gómez C. (2010). La ruta agroturística del queso Turrialba. In H. Hernando Riveros, A. Lucio-Paredes, \& M. Blanco (eds.), Una mirada a experiencias exitosas de agroturismo en América Latina. San José, Costa Rica: Instituto Interamericano de Cooperación para la Agricultura.

Britton, S. (1991). Tourism, capital and place: Towards a critical geography of tourism. Environment and Planning D: Society and Space, 9, 457-478.

Boukris, L. (2013). Du produit touristique à la figure territoriale patrimonialisée: La route du fromage Turrialba, Costa Rica. Food Geography, 2, 31-41.

Cantarelli, F. (2001). Formaggi tipici e turismo. Economia agro-alimentare, 1, 44-71.

Chen, Q., \& Huang, R. (2016). Understanding the importance of food tourism to Chongqing, China. Journal of Vacation Marketing, 22(1), 42-54.

Crespí-Vallbona, M., \& Domínguez Pérez, M. (2015). Los mercados de abastos y las ciudades turísticas. PASOS Revista de Turismo y Patrimonio Cultural, 14(2), 401-416.

Delfosse, C. (2017). Les crémiers-fromagers. Entre commerce de proximité et gastronomie. Paris: Presses Universitaires de France.

Dimitrovski, D., \& Crespí-Vallbona, M. (2017). Role of food neophilia in food market tourists' motivational construct: The case of La Boqueria in Barcelona, Spain. Journal of Travel and Tourism Marketing, 34(4), 475-487. 
Dumas, L., Menvielle, W., Perreault, D., \& Pettigrew, D. (2006). Terroirs, agrotourisme et marketing: Le cas des fromages québécois. Téoros, 25(1), 34-41.

Ellis, A., Park, E., Kim, S., \& Yeoman, I. (2018). What is food tourism?. Tourism Management, $68,250-263$.

Everett, S. (2016). Food and drink tourism: Principles and practice. London: Sage.

França, O.E. (2012). O caso Queijo do Serro como Sistema Agroalimentar Local - SIAL: Complementaridade entre produção agroalimentar e turismo. Brasília: Programa de Pós Graduação em Agronegócios, FAV, Universidade de Brasília.

Fusté Forné, F. (2015). Cheese tourism in a World Heritage Site: Vall de Boí (Catalan Pyrenees). European Journal of Tourism Research, 11, 87-101.

Fusté Forné, F. (2016a). Tasting cheesescapes in Canterbury (New Zealand). New Zealand Geographer, 72(1), 41-50.

Fusté Forné, F. (2016b). Cheese Tourism: local produce with protected designation of origin in the region of Galicia, Spain. In: C.M. Hall, \& S. Gössling (eds.), Food Tourism and Regional Development: Networks, products and trajectories, 242-252. Abingdon: Routledge.

García Henche, B. (2017). Los mercados de abastos y su comercialización como producto de turismo de experiencias. El caso de Madrid. Cuadernos de Turismo, 39, 167-189.

Hall, C.M. (2016). Heirloom products in heritage places: Farmers markets, local food, and food diversity. In: D. Timothy (ed.), Heritage Cuisines: Traditions, identities and tourism, 88103. Abingdon: Routledge.

Hall, C.M., \& Sharples, L. (2008). Food and Wine Festivals and Events Around the World: Development, management and markets. Oxford: Elsevier.

Hall, C.M., Sharples, L., Mitchell, R., Macionis, N., \& Cambourne, B. (2003). Food Tourism Around the World: Development, management, and markets. Oxford: Elsevier.

Harrington, R.J. and Seo, H.S. (2015). The Impact of Liking of Wine and Food Items on Perceptions of Wine-Food Pairing. Journal of Foodservice Business Research, 18(5), 489-501.

Medina, F.X. (2008). Mercados urbanos en Europa: Patrimonio y promoción turística. In: M. Álvarez, \& F.X. Medina (eds.), Identidades en el plato. El patrimonio cultural alimentario entre Europa y América, 207-220. Barcelona: Icaria.

Roy, H., Hall, C.M., \& Ballantine, P. (2016). Barriers and constraints in the use of local foods in the hospitality sector. In: C.M. Hall, \& S. Gössling (eds.), Food Tourism and Regional Development: Networks, products and trajectories, 255-272. Abingdon: Routledge.

Roy, H., Hall, C.M., \& Ballantine, P. (2017). Trust in local food networks: The role of trust among tourism stakeholders and their impacts in purchasing decisions. Journal of Destination Marketing and Management, 6(4), 309-317.

Sidali, K.L., Kastenholz, E., \& Bianchi, R. (2015). Food tourism, niche markets and products in rural tourism: combining the intimacy model and the experience economy as a rural development strategy. Journal of Sustainable Tourism, 23(8-9), 1179-1197.

Sims, R. (2009). Food, place and authenticity: Local food and the sustainable tourism experience. Journal of Sustainable Tourism, 17(3), 321-336.

Smith, S.L.J., \& Xiao, H. (2008). Culinary tourism supply chains: A preliminary examination. Journal of Travel Research, 46(3), 289-299. 
Fusté-Forné, F.

Thomé, H., Vizcarra, I., \& Espinoza, A. (2015). Performancia y fractalización como herramientas de metabolización de los espacios rurales. El caso de la Ruta del Queso y el Vino de Querétaro. Spanish Journal of Rural Development, 6(1), 29-44. 